\title{
The Influence of Urbanization on the Behaviour of Dogs in the Czech Republic
}

\author{
E. BARANYIOVÁ ${ }^{1}$, A. HOLUB, M. TYRLIIK ${ }^{2}$, B. JANÁČKOVÁ ${ }^{3}$, M. ERNSTOVÁ ${ }^{4}$ \\ ${ }^{1}$ Department of Veterinary Public Health and Toxicology, Faculty of Veterinary Hygiene and Ecology, \\ University of Veterinary and Pharmaceutical Sciences, ${ }^{2}$ Faculty of Arts, Institute of Psychology, Masaryk \\ University Brno, ${ }^{3}$ Ministry of Agriculture of the Czech Republic, Prague, ${ }^{4}$ Pfizer, Ltd., Prague, Czech Republic
}

\author{
Received July 14, 2004 \\ Accepted August 30, 2005
}

\begin{abstract}
Baranyiová E., A. Holub, M. Tyrlík, B. Janáčková, M. Ernstová: The Influence of Urbanization on the Behaviour of Dogs in the Czech Republic. Acta Vet. Brno 74, 2005: 401-409.

The aim of this study was to evaluate the influence of urbanization in the Czech Republic upon the co-existence of domesticated dogs and their owners. We divided the data from a questionnaire (distributed to dog owners) into rural $(\mathrm{R}, \mathrm{n}=164)$ and urban $(\mathrm{U}, \mathrm{n}=132)$. The former group comprised of dogs living in family houses with yards/gardens, the latter comprised of dogs kept in urban apartments without yards or gardens. The data were evaluated by chi-square test.

The differences in living conditions of $\mathrm{R}$ and $\mathrm{U}$ dogs were derivative of different structures of the respective households. In the R group, $3.7 \%$ of dogs lived in one-person households, $42.9 \%$ in two-person, and $53.4 \%$ in households with more than two persons. By contrast in U households more dogs lived in one-person households (6.9\%), 58.8\% in two-member, but fewer (34.4\%) lived in households with more members. In R households, more frequently other dogs also were living $\left(\mathrm{R}=60.1 \%, \mathrm{U}=32.1 \% ; \chi^{2}=22.929, \mathrm{df}=1 ; p<0.001\right)$, and a linear association was found with the larger number of children and cats and other animals in the house.

Although the physical and social pressures upon the U group of dogs, based on permanent dwelling in small niches of urban apartments, were very strong (Czech apartments are comfortable, but smaller than in many other European countries), we found significant changes in 23 (27.1\%) of 86 behavioural traits analyzed. Among them, however, only 6 (14.6\%) from among 41 traits concerned behaviours of dogs (using the furniture, sleeping in beds of family members, mounting people, growling at family members, perceiving the moods of owners, showing fear, and destroying garden less frequently). The remaining 44 traits under study concerned the behaviour of owners/family members. In this category we found 17 significant differences. Their proportion was more than 2.5 times greater (i.e. $38.6 \%$ ) than that of differences in the behaviour of dogs.

We concluded that although the characteristics of co-existence of people and their dogs under study have different biological significance, it is obvious that in the urbanized environment of the Czech society, as this co-existence became more intense, the contacts between people and their dogs became more intimate. Furthermore, household members changed their behaviour (i.e., showed more changes in their conduct) more than their dogs. This transformation of behaviour notwithstanding, with even more rapid urbanization of human society, dogs are still viewed as desirable and suitable companions for humans. No doubt, this is because dogs possess an outstanding social cognition vis-á-vis people and even in an urban environment they are able to adapt and thrive under new conditions of the inter-species co-existence, i.e., contributing to the human-animal bond.
\end{abstract}

Behavioural traits, rural and urban living, questionnaire, human-animal bond

Dogs, our most ancient companions, nowadays accompany humans around the globe, under the most diverse life conditions (Matter and Daniels 2000), including relatively recent factors related to urbanization, the growing role of urban agglomerations in human communities. This development brings new problems for people living in high-density living settings, such as barking dogs, damage to furniture and household equipment, and aggression of dogs (e.g. Beck 1992; Hart and Hart 1996; Hunthausen 1996).

We have access to reliable data about the process of urbanization in the Czech territory for about 150 years. There are data available on where and how people live, their apartments

\footnotetext{
Address for correspondence:

E. Baranyiová

Department of Veterinary Public Health and Toxicology

University of Veterinary and Pharmaceutical Sciences
}

Palackého 133, 61242 Brno

Czech Republic

Phone: + 412241562791

E-mail: actavet@vfu.cz 
and household furnishings. For example, in 1857, only $3 \%$ of inhabitants lived in cities. By 1957, this number had increased tenfold, to $35 \%$. Statistical data from the recent decades show that the urbanization has further accelerated. From the 1960 s to 1980 s, the number of urban apartments had increased by one third. In 1991, they comprised nearly one third of all of dwellings. Their number continued to increase during the 1990s and in 1998, there were 3,706,000 urban apartments in the country. Rural dwellings represented only about one third of the total number of dwellings (Statistics Yearbook of the Czech Republic, 1998). Moreover, apartments/houses in the rural areas were occupied less frequently than urban apartments. Whereas the number of uninhabited homes in the cities was $5.7 \%$, in rural areas it reached $16.2 \%$, i.e., nearly 3 times more. In villages with up to 200 inhabitants as many as $91.0 \%$ of living quarters were uninhabited (Dupal et al.1999).

These changes in the mode of living necessarily affected the living conditions of our closest companion species, the dogs. Dogs also became a part of the urbanization of the Czech society. A large proportion of dogs were translocated from backyards, kennels, and gardens into apartments with central heating, kitchens, living rooms, and bedrooms designed for people wishing to enjoy the amenities of city dwelling. The dogs are taken out of these highly technical niches for walks along concrete, stone, and asphalt-covered streets and sidewalks. They experience green areas such as parks or forests less frequently and then for only short periods.

It can be assumed that the co-existence of humans and their dogs under different conditions of rural and urban environments takes different forms, and urbanization may also have some negative aspects as in other countries (e.g. Beck 1992). Since no adequate attention has been devoted to this change, we decided to explore it in detail.

\section{Materials and Methods}

The data pool of the dogs presented earlier (Baranyiová et al. 2001, 2004) was for this study divided into two groups comprising a total of 296 dogs. Group R (rural): 164 dogs reared in the rural environment, in family houses with yards and gardens used by the dogs, and group U (urban): 132 dogs living in urban apartments (with access to outdoors for short walks on leash and often muzzled). The data were obtained from the modified questionnaire based on Askew (1997) and Podberscek and Serpell (1996). The questionnaire was published in a monthly magazine. Most data (about 90\%) came from readers of "Náš pes" ("Our Dog") and the remainder was obtained from clients of veterinary clinics.

We analyzed 85 traits belonging to several categories: basic data about both groups of dogs: sex and breed, their age at acquisition, and health status. We divided the dogs by size into five groups: toy (body mass less than $5 \mathrm{~kg}$ ), small (5-10 kg), middle-size (10-17 kg), large (17-33 kg), and giant (more than $33 \mathrm{~kg})$ (Lewis et al. 1987; Kraft 1998). We further evaluated information about the family structure (numbers of adults, children, and other animals), housing type (the apartments in our study had in average $72 \pm 27 \mathrm{~m}^{2} ; 115$ owners reported $61 \pm 17 \mathrm{~m}^{2}$, and 30 reported $112 \pm 19 \mathrm{~m}^{2}$ ), care of the dogs (daily regime, feeding and walking routine, types of games, playing with people and other dogs), obedience of the dogs. Other behavioural characteristics were evaluated, including those negatively perceived by their owners (e.g., aggression) and their general position in the household as well. For statistical evaluation of the results we used $\chi^{2}$ test from the statistical software SPSS v. 8 .

\section{Results}

The $\mathrm{R}$ and $\mathrm{U}$ groups under study may be characterized as follows: both sexes were represented equally (males, $\mathrm{R}=50.0 \%$, males, $\mathrm{U}=48.5 \%$, females $\mathrm{R}=50.0 \%, \mathrm{U}=50.7 \%$ ). No information about neutering was available. Puppies did not differ in the age at which they were acquired: about two thirds of them $(\mathrm{R}=64.4 \%, \mathrm{U}=68.2)$ at the age between 6 and 10 weeks, others at the age of 6 weeks to 6 months $(\mathrm{R}=24.5 \%, \mathrm{U}=26.5 \%)$. The remainder of the dogs was acquired at an older age $(\mathrm{R}=11.0 \%, \mathrm{U}=5.3 \%)$.

$\mathrm{R}$ and $\mathrm{U}$ dogs, however, differed in their breeds/sizes: the proportion of large and giant dogs was significantly higher $(p<0.05)$ in the $\mathrm{R}$ group (Fig. 1).

Different life conditions of $\mathrm{R}$ and $\mathrm{U}$ dogs followed from different structures of the respective households: in the R group, only $3.7 \%$ of dogs lived in one-person households, 


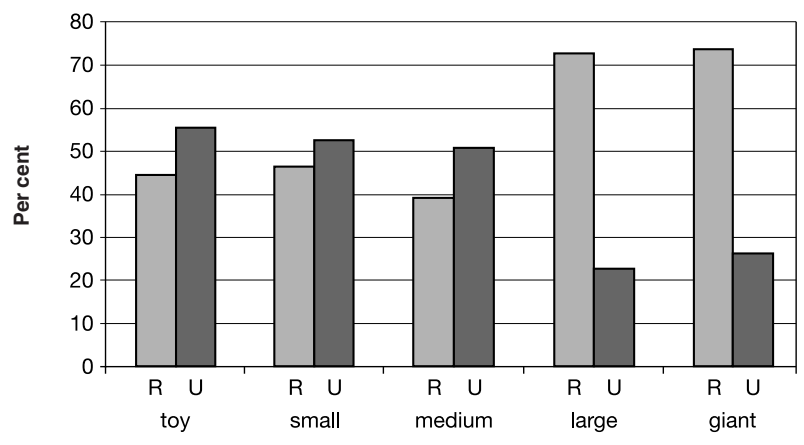

Fig. 1. Percentage of dogs of various sizes in rural and urban households of the Czech Republic

$42.9 \%$ in two-person households, and $53.4 \%$ in families consisting of more than two persons. In the U group, however, $6.9 \%$ of dogs lived in one-person households, $58.8 \%$ in two-person, and fewer $(34.4 \%)$ in families numbering more than two people. In $\mathrm{R}$ households, people more frequently kept another dog or dogs $(\mathrm{R}=60.1 \%, \mathrm{U}=32.1 \%$, $\left.\chi^{2}=22.929, \mathrm{df}=1 ; p<0.001\right)$, and there was a linear association between a larger number of children and cats or other animals kept in the family.

When analyzing the conduct of the owners and family members in reference to their dogs, we found that there were practically no differences in feeding the dogs. In both $\mathrm{R}$ and $\mathrm{U}$ households the dogs had permanent access to drinking water $(\mathrm{R}=92.2 \%, \mathrm{U}=99.2 \%)$, and they were fed before family meals were served $(\mathrm{R}=84.4 \%, \mathrm{U}=79.1 \%)$. $\mathrm{R}$ and $\mathrm{U}$ people shared the food, gave treats of own food to their $\operatorname{dogs}(\mathrm{R}=80.2 \%, \mathrm{U}=81.8 \%)$, and they fed them once a day $(\mathrm{R}=57.5 \%, \mathrm{U}=57.6 \%)$. With both housing styles, owners used treats in training their dogs $(\mathrm{R}=68.6 \%, \mathrm{U}=65.3 \%)$, and they fed them table scraps $(\mathrm{R}=8.1 \%, \mathrm{U}=$ $5.3 \%)$. However, two significant differences were found: $\mathrm{R}$ dogs were less frequently given human food from the table $\left(\mathrm{R}=27.8 \%, \mathrm{U}=46.2 \%, \chi^{2}=10.721, \mathrm{df}=1 ; p<0.001\right)$, especially during family meals $\left(\mathrm{R}=19.4 \%, \mathrm{U}=31.8 \%, \chi^{2}=9.573, \mathrm{df}=1 ; p<0.01\right)$.

Significant differences between $\mathrm{R}$ and $\mathrm{U}$ dogs were detected in exercising. $\mathrm{R}$ dogs were regularly walked less frequently $\left(\mathrm{R}=52.1 \%, \mathrm{U}=84.7 \%, \chi^{2}=34.704, \mathrm{df}=1 ; p<0.001\right)$, and, when walked in forests or parks, they were more frequently on the leash $(\mathrm{R}=8.0 \%, \mathrm{U}=$ $\left.1.5 \%, \chi^{2}=6.307, \mathrm{df}=1 ; p<0.01\right)$ than $\mathrm{U}$ dogs. In other attributes of walks, such as time of the day $(\mathrm{R}=51.8 \%, \mathrm{U}=50.0 \%)$, walking dogs on leash only in the streets $(\mathrm{R}=76.2 \%, \mathrm{U}=$ $80.3 \%)$ or walking them on leash always and everywhere $(\mathrm{R}=14.6 \%, \mathrm{U}=10.6 \%)$, no significant differences were found.

Similarly, no significant differences occurred in play. Both $R$ and $U$ dogs played with their owners at home $(\mathrm{R}=81.1 \%, \mathrm{U}=76.7 \%)$, during walks $(\mathrm{R}=72.0 \%, \mathrm{U}=72.0 \%)$, and at other occasions $(\mathrm{R}=37.9 \%, \mathrm{U}=35.8 \%)$. They were engaged in different games, such as tug-ofwar $(\mathrm{R}=68.9 \%, \mathrm{U}=71.2 \%)$, retrieving objects $(\mathrm{R}=70.7 \%, \mathrm{U}=65.9 \%)$, but also other games $(\mathrm{R}=75.0 \%, \mathrm{U}=71.2 \%)$, including those using physical strength $(\mathrm{R}=28.0 \%, \mathrm{U}=$ $32.6 \%)$. Dogs were allowed to play with other dogs sometimes $(\mathrm{R}=53.0 \%, \mathrm{U}=53.0 \%)$, often $(\mathrm{R}=28.7 \%, \mathrm{U}=24.2 \%)$, or regularly $(\mathrm{R}=9.8 \%, \mathrm{U}=9.8 \%)$.

Likewise, no differences were found in training and obedience to basic commands. More than a half of dogs in both groups had basic obedience training $(\mathrm{R}=54.4 \%, \mathrm{U}=56.9 \%)$, however, only $1 / 6$ of them under a professional trainer guidance $(\mathrm{R}=15.8 \%, \mathrm{U}=18.3 \%)$. On the other hand, urban owners took their dogs significantly more often for travel, vacations, and celebrated their birthdays (Table 2). 
Table 1. Behavioural traits of dogs (in per cent)

\begin{tabular}{|l|c|c|c|}
\hline Behaviour & Rural & Urban & Significance \\
\hline & $\%$ & $\%$ & \\
\hline Defends family members and items & 77.8 & 73.8 & \\
\hline Is allowed on the furniture & 63.4 & 87.1 & $(\chi 2=21.356 ; \mathrm{df}=1 ; p<0.001)$ \\
\hline Is allowed to sleep in beds of family members & 42.6 & 74.2 & $(\chi 2=29.693 ; \mathrm{df}=1 ; p<0.001)$ \\
\hline Is aggressive when threatened & 50. & 50.8 & \\
\hline Barks excessively and growls at strangers & 50.0 & 46.2 & \\
\hline Licks and scratches him/herself & 42.5 & 46.5 & \\
\hline Shows coprophagia & 37.4 & 38.9 & \\
\hline Shows mounting & 21.0 & 42.4 & $(\chi 2=15.735 ; \mathrm{df}=1 ; p<0.001)$ \\
\hline Barks excessively, whines or howls & 26.5 & 30.5 & \\
\hline Destructive in the yard & 30.2 & 14.0 & $(\chi 2=10.627 ; \mathrm{df}=1 ; p<0.001)$ \\
\hline Growls at family members & 11.7 & 24.4 & $(\chi 2=8.125 ; \mathrm{df}=1 ; p<0.005)$ \\
\hline Masturbates & 13.5 & 21.1 & \\
\hline Destructive in home & 14.8 & 18.5 & \\
\hline Urinating in home & 14.7 & 16.3 & \\
\hline Aggrressive when disturbed while sleeping/resting & 11.9 & 13.1 & \\
\hline Aggressive when eating & 12.6 & 10.0 & \\
\hline Roaming & 12.3 & 9.9 & \\
\hline Biting strangers & 12.5 & 8.5 & \\
\hline Aggressive when brushed & 11.0 & 7.7 & \\
\hline Aggressive when pushed & 5.6 & 10.0 & \\
\hline Aggressive when reached for & 3.1 & 5.4 & \\
\hline Aggressive when touched & 3.1 & 2.3 & \\
\hline
\end{tabular}

Table 2. Characteristics of dogs (in per cent)

\begin{tabular}{|l|c|c|l|}
\hline Behaviour & Rural & Urban & Significance \\
\hline & $\%$ & $\%$ & \\
\hline Playful & 96.1 & 95.1 & \\
\hline Obedient & 80.0 & 88.8 & \\
\hline Very active & 80.7 & 75.7 & \\
\hline Disobedient & 59.4 & 63.1 & \\
\hline Stubborn & 47.9 & 53.9 & \\
\hline Dominant & 47.5 & 50.5 & \\
\hline Fearful & 35.8 & 47.2 & $\left(\chi^{2}=3.793 ; \mathrm{df}=\right.$ \\
& & & $1 ; p<0.05)$ \\
\hline Submissive & 35.0 & 37.6 & \\
\hline Nuisance & 32.7 & 21.1 & \\
\hline Nervous & 19.6 & 29.3 & \\
\hline Difficult to control & 20.6 & 21.6 & \\
\hline Hypoactive & 20.0 & 20.0 & \\
\hline
\end{tabular}

Table 3. Position of the dog in household (in per cent)

\begin{tabular}{|l|c|c|c|}
\hline Behaviour & Rural & Urban & Significance \\
\hline & $\%$ & $\%$ & \\
\hline Considered family member & 98.2 & 100.0 & \\
\hline Daily spoken to & 95.7 & 97.0 & \\
\hline Affectionate & 94.5 & 94.6 & \\
\hline Dog's photographs & & & \\
in the household & 93.9 & 95.5 & \\
\hline Dog perceives moods & & & \\
of family members & 91.5 & 96.9 & $\left(\chi^{2}=3.822 ; \mathrm{df}=1 ; p<0.05\right)$ \\
\hline Family members & & & \\
\hline perceive dog's moods & 92.6 & 95.5 & \\
\hline Dog taken for vacation & 72.0 & 92.4 & $\left(\chi^{2}=19.502 ; \mathrm{df}=1 ; p<0.001\right)$ \\
\hline Family members & & & \\
\hline confide to dog & 83.2 & 81.7 & \\
\hline Dog is companion & 68.9 & 84.5 & $\left(\chi^{2}=9.580 ; \mathrm{df}=2 ; p<0.01\right)$ \\
\hline Dog's birthdays celebrated & 62.5 & 75.0 & $\left(\chi^{2}=5.207 ; \mathrm{df}=1 ; p<0.02\right)$ \\
\hline
\end{tabular}


Analysis of dog behaviour traits revealed the following: the owners found their dogs for the most part obedient $(\mathrm{R}=80.0 \%, \mathrm{U}=88.8 \%)$. In both rural and urban environments they defended items and family members. At the same time they were found sometimes disobedient $(\mathrm{R}=59.4 \%, \mathrm{U}=63.1 \%)$, and one fifth of the dogs were found sometimes difficult to control $(20.6 \%, \mathrm{U}=21.6 \%)$. The command "sit" was consistently obeyed by the majority of dogs $(\mathrm{R}=64.6 \%, \mathrm{U}=77.3 \%)$, the command "down" was always obeyed by less than half of the dogs $(\mathrm{R}=43.5 \%, \mathrm{U}=40.6 \%)$, the command "come" was always obeyed by even fewer dogs $(\mathrm{R}=23.3 \%, \mathrm{U}=22.9 \%)$. The dogs were found to lick and scratch themselves excessively, were coprophagic, barked, whined and howled excessively, masturbated, they destroyed household items, house-soiled, and roamed. However, in several traits the two groups differed significantly. $\mathrm{R}$ dogs stole human food $(\mathrm{R}=50.6 \%$, $\left.\mathrm{U}=77.3 \%, \chi^{2}=4.553, \mathrm{df}=1 ; p<0.05\right)$ and they destroyed gardens more frequently. $\mathrm{U}$ dogs, on the other hand, significantly more often used the household furniture, slept in beds of the family members and attempted to mount them (Table 1).

Numerous complaints of the respondents concerned aggressive behaviours of their dogs. Both groups have shown aggression when threatened, barked, growled at strangers and even bit them, they were aggressive when disturbed in sleep, when feeding, when being brushed, when pushed away, when reached toward, and when simply touched. However, there was only one significant difference: $U$ dogs growled more often at family members (Table 1).

Our respondents provided relatively objective profiles of the behaviours of their dogs and put them into broader time contexts, and construed further characteristics and perceptions. They considered their dogs, both R and U, to be playful, active or hyperactive, obedient or disobedient, dominant, stubborn, difficult to control, viewed as a nuisance, submissive, nervous or hypoactive with no differences according to group. Only in one trait, a significant difference was found: $\mathrm{R}$ dogs were less fearful than U dogs (Table 2).

Based on these traits showing the adaptation of dogs to life in rural and urban households the owners made further judgements concerning the position of their dog in the household. Almost all owners considered the dogs as household members, faithful, and they reported talking daily to their dogs. There were dog photographs in the homes, the owners declared that they could perceive the moods of their dogs, they communicated to them important matters, and considered them as companions. We found a linear association in that $\mathrm{R}$ dogs were less often viewed as companions only $(\mathrm{R}=68.9 \%, \mathrm{U}=84.5 \%)$, but were more frequently engaged as working dogs $\left(\mathrm{R}=29.3 \%, \mathrm{U}=14.7 \%, \chi^{2}=9.580, \mathrm{df}=2 ; p<0.01\right)$. $\mathrm{U}$ dogs were significantly more often credited with perceiving the moods of their owners (Table 3).

\section{Discussion}

The effect of housing types upon behaviour of dogs has been investigated in recent years (Hetts 1991; Hetts et al. 1992; Hubrecht et al.1992; Hubrecht 1995). It has been found that changes in housing styles may alter the behaviours of dogs. Both physical and social deprivation ensuing from the environmental change may have far-reaching consequences and result in abnormal/undesirable behaviours (Hetts et al. 1992; Hubrecht 1995; Houpt and Will is 2001), affect the welfare of dogs (Baranyiová and Holub 2004), and lead to a break of the human-animal bond (e.g. Houpt et al. 1996).

Dogs in our $U$ group had been exposed to such housing restrictions for a long time, from an early age (two thirds of their number from the age of six-to-ten weeks, another fourth of their number from the age of six months) (Freedman et al. 1961; Scott 1962, 1992). Puppies were adopted early and thus in the highly formative phase of their lives, when the inter-individual and inter-species contacts develop rapidly and have significant and long- 
lasting influence upon behaviour (Scott and Marston 1950; Scott and Fuller 1965, 1974). R dogs spent most of their time in backyards or gardens and green areas; some of them never entered the living quarters of the family. U dogs on the other hand, were kept from their socialization period in very restricted conditions of limited space of town apartments, with central heating and other comforts designed for people. Dogs in the $\mathrm{U}$ group were leaving these small niches only briefly, when they were taken out for elimination or for walks with human supervision and mostly to streets or parks. Hence their co-existence with humans was much closer, intimate and intensive.

The U dogs were kept almost exclusively for human pleasure. The original use of these dogs for work has disappeared. Several of their behaviours, once valued and selected, began to be a nuisance and were considered objectionable, undesirable, and even unwanted. These dogs often posed serious problems when left by themselves for long hours in small urban apartments, separated from their owners. For example, Flannigan and Dodman (2001) reported that dogs living with a single adult human were approximately two and half times as likely to suffer from separation anxiety as dogs living with two or more people. Importantly, our U dogs were restricted in space much more than is usual for dogs in other countries; apartments in urban high-density living settings of the Czech Republic, though well equipped, are smaller than those in West European (Austria, France, Germany, Switzerland, Sweden United Kingdom), but also East European (Belarus, Croatia, Hungary, Latvia, Poland, Russia) countries. The apartments in our study had in average $72 \pm 27 \mathrm{~m}^{2}$ (115 owners reported $61 \pm 17 \mathrm{~m}^{2}$, and 30 reported $112 \pm 19 \mathrm{~m}^{2}$ ). This size is about one third of the size reported for the USA (Annual Bulletin of Housing and Building Statistics for Europe and North America 1998).

Despite these strong physical constraints/stresses, surprisingly few significant changes were reported in the co-existence of people and their dogs in R vs U environments. The actual and expected frequencies of responses were similar to our previous results, in which the housing style was not included as a criterion (Baranyiová et al. 2001, 2004). Various behavioural traits such as aggression, we found more frequently than investigators in other countries (Fraser and Rushen 1987; Beaver 1999; Overall 1997; Baranyiová et al. 2001).

Nevertheless, the responses of dog owners do reveal several significant differences in the co-existence of people and dogs in R and U environments: from the total number of 85 traits, 23 (i.e. $27.1 \%$ ) were different. The differences in the behaviours of dogs included more frequent mounting of people in $U$ dogs (i.e., a symptom of conflict behaviour) compared to $\mathrm{R}$ dogs; they were more fearful, growled at family members and it is assumed that they perceived their moods; on the other hand, they destroyed gardens less than R dogs, stole human food and showed a specific age-related course of morbidity. Compared with R dogs, in $\mathrm{U}$ dogs only six traits out of 41 (i.e., 14.6\%) showed significant differences.

However, more differences were observed in the conduct of the owners toward the dogs, i.e., in the human component, the family members, of the data set. For example, the $\mathrm{U}$ households showed a different structure in contrast to the $\mathrm{R}$ households. They had significantly fewer adult members and children, and there were fewer animals kept along with the family dog (a second dog, cats and other pets). Dogs were thus living not only in different physical, but also a different social environment. The groups were less numerous, less complicated with a fewer number of conspecific and heterospecific interactions (Miklósi et al. 2004). Furthermore, people in U environments preferred smaller dogs, and giant and large breeds were less frequent in these households.

The care of dogs was also different in U households: they were considered exclusively as companions, were significantly more often allowed to use furniture, sleep in beds of their owners, and participate in family meals. During meals, but also at other times, the owners gave them both human food and treats. They also significantly more frequently took the dogs 
out to eliminate, to walk in parks, allowed them to move freely (with no leash), but kept in contact and controlled them, always accompanied and followed their dogs, took them on travel and vacation and celebrated their birthdays. Thus our results thus show that urbanization affected significantly 17 of $44(38.6 \%)$ behavioural patterns/traits initiated by people. Mutual contacts of family members and dogs increase in number and their coexistence is becoming more intensive.

Similar conclusions are presented by Beck and Katcher (1996) who suggest that such phenomena may be considered a compensation for changes in life styles of people in the urbanized world. This may even create a privileged position of dogs in the small niches of urban apartments, where people are seen to tolerate more nuisance behaviours of their dogs than of their children. Compared to R environment, people in U milieu seemingly adapt their own behaviours in more than double the traits than do their dogs. Despite the fact that these significantly changing features/traits have different biological importance, it is obvious that people in the Czech Republic do adapt their behaviours more to co-existence with their dogs than do the dogs in the urbanized environment.

In this context it should be stressed that attitudes toward dogs in the Czech Republic are highly polarized. Our respondents belong to the pet owners that have a positive attitude to dogs, being interested in them, buying dog magazines and other literature, and seeking veterinary help when needed (Baranyiová et al. 2001, 2004). This fact of self-selection of the respondents surely influenced the results of our study.

The history of changes in the bond of humans and their dogs is rich. In the course of their co-existence both species have spread over the globe, into all climatic regions. They continue to exert a strong mutual selection pressure. All dogs today are products of human activities. In the course of their common evolution the dogs have shown outstanding social cognition (Hare et al. 2002; Miklósi et al. 2004). This notion is also fully supported by our results. It can thus be assumed that both human and canine populations do adapt to the expanding urbanization process (Hagman 2001) and that they will continue to be companions under these new conditions. However, a problem meriting ongoing study is the magnitude of changes and depth of adaptation in both species that will ensue from this coexistence.

\section{Vliv urbanizace na chování psů v České republice}

Předmětem našeho zájmu bylo hodnocení vlivu urbanizace české společnosti na její soužití se psy. Za tím účelem jsme sledovaný soubor rozdělili do dvou skupin, na venkovskou $(\mathrm{R})(\mathrm{n}=164)$ a městskou $(\mathrm{U})(\mathrm{n}=132)$. V první žili psi v rodinných domcích $\mathrm{s}$ výběhem, $\mathrm{v}$ druhé $\mathrm{v}$ bytech městských nájemných domů. Potřebná data jsme získali pomocí dotazníků a výsledky byly hodnoceny $\chi^{2}$ testem.

Rozdíly životních podmínek R a U psů vyplývají i z rozdílné struktury domácností. Ve venkovské skupině žije jen 3,7 \% psů v domácnostech jednočlenných, 42,9 \% ve dvoučlenných a $53,4 \%$ v ještě četnějších. Ve městech je jich v domácnostech jednočlenných víc, $6,9 \%$, ve dvoučlenných 58,8\%, ale ve vícečetných méně, jen 34,4\%. V R domácnostech se častěji chovají další psi $\left(\mathrm{R}=60,1 \%, \mathrm{U}=32,1 \%, \chi^{2}=22,929 ; \mathrm{df}=1 ; p<0,001\right)$ a projevuje se $\mathrm{v}$ nich i lineární asociace $\mathrm{s}$ větším počtem dětí a s chovem koček a některých dalších živých tvorů.

I když fyzikální a sociální tlaky na U skupinu psů, vyplývající z trvalého pobytu v malých nikách městských nájemních bytů, byly velmi silné (české sídlištní byty jsou sice komfortní, ale menší než v četných zemí Evropy), zjistili jsme v U prostředí průkazné změny jen u 23 $(27,1 \%)$ z 86 analyzovaných znaků. Z toho se jich však jen 6 (14,6 \%) (psi častěji využívali zařízení bytu a spali v postelích, skákali na nohu, vrčeli na členy domácností, vnímali nálady lidí, byli ustrašení a naopak méně ničili zahradní porosty) z 41 projevů týkalo chování psů. 
O ostatních 44 sledovaných parametrech rozhodovali lidé, členové domácností. V této kategorii jsme zaznamenali 17 významných změn. Jejich podíl byl tudíž ve srovnání s diferencemi v chování U psů víc než dvaapůlnásobný $(38,6 \%)$.

Závěrem možno konstatovat, že třebaže mají sledované znaky soužití lidí a psů různý biologický význam, je zřejmé, že u nás v urbanizovaném prostředí koexistence psů a lidí nabyla na intenzitě, jejich vzájemné kontakty na těsnosti a že členové domácností podstupují více změn svého jednání než jejich psi. Přesto jsou psi ve stále rychleji probíhající urbanizaci lidských societ pokládání za vhodné, žádoucí společníky. Mají totiž vynikající sociální kognici lidí a jsou s to se $\mathrm{v}$ urbanizovaném prostředí novým podmínkám mezidruhového svazku s lidmi i adaptovat.

\section{References}

Annual Bulletin of Housing and Building Statistics for Europe and North America. 1998. Vol 39, 1997. Genève ASKEW HR 1997: Behandlung von Verhaltensproblemen bei Hund und Katze. Parey, Berlin. VII and $372 \mathrm{p}$.

BARANYIOVÁ E, HOLUB A, JANÁČKOVÁ B, ERNSTOVÁ M 2001: Výpovědi chovatelů o psech v České republice. Veterinářství 51: 167-171

BARANYIOVÁ E, HOLUB A, TYRLÍK M, JANÁČKOVÁ B, ERNSTOVÁ M 2004: Behavioural differences of dogs of various ages in Czech households. Acta Vet Brno 73: 229-233

BARANYIOVÁ E, HOLUB A 2004: Welfare, věda, veterinární medicína (Welfare, science and veterinary medicine). Ochrana zviřat a welfare 2004, FVHE VFUB, Part A, pp. 12-15 (ISBN 80-7305-500-7)

BEAVER BV 1999: Canine behavior: a guide for veterinarians.W B Sauders Company, Philadelphia. 355 p.

BECK AM 1992: Health and behavioral implications of pet ownership. In: Behavioral problems in Small Animals. Purina Specialty Review, Pro Visions, pp. 4-12

BECK AM, KATCHER A 1996: Between pets and people. Purdue University Press, West Lafayette, IN, USA. 316 p.

DUPAL J, ANDRLE A, TOMÁŠ Z, FISCHEROVÁ B, MAŤOVÁ M 1999: Př́rručka o bydlení v České republice. Etapa. Terplan, Praha, $236 \mathrm{p}$.

FLANNIGAN G, DODMAN NH 2001: Risk factors and behaviors associated with separation anxiety in dogs. J Am Vet Med Assoc 219: 460-466

FOX MW 1968: Abnormal behavior in animals. W.B. Saunders, Philadelphia

FRASER D, RUSHEN J 1987: Aggressive behavior. Vet Clin North Amer Food Anim Pract 3: 285-305

FREEDMAN DG, KING JA, ELLIOT E 1961: Critical period in the social development of dogs. Science 133: 1016-1017

HAGMAN M 2001: The world in 2050: more crowded, urban and aged. Bulletin WHO 79, p. 484

HARE B, BROWN M, WILLIAMSON C, TOMASELLO M 2002: The domestication of cognition in dogs. Science 298: 1634-1636

HART BL, HART LA 1996: Selecting, raising, and caring for dogs to avoid problem aggression. J Am Vet Med Assoc 210: 1129-1134

HETTS S 1991: Psychologic well-being: behavioral measures and implications for the dog. In: Advan in Comp Anim Behav 21: 369-387

HETTS S, CLARK JD, CALPIN JP, ARMNOLD CP, MATEO JM 1992: Influence of housing conditions on beagle behaviour. Appl Anim Behav Sci 34: 137-155

HOUPT KA, HONIG SU, RESINER IR 1996: Exploring the bond - Breaking the human companion animal bond. J Am Vet Med Assoc 209: 1653-1659

HOUPT KA, WILLIS MB 2001: Genetics of Behaviour. In: The Genetics of the Dog. CABI Publishing, Wallingford, New York. p. 371-400

HUBRECHT RC, SERPELL JA, POOLE TB 1992: Correlates of pen size and housing conditions on the behaviour of kennelled dogs. Appl Anim Behav Sci 34: 365-383

HUBRECHT R 1995: The welfare of dogs in human care. In: The domestic dog, its evolution, behaviour, and interactions with people. Cambridge University Press, Cambridge, pp. 179-198

HUNTHAUSEN W 1996: Effects of aggressive behavior on canine welfare. J Am Vet Med Assoc 210: 1134-1139

KRAFT W: Einführung. In: Geriatrie bei Hund und Katze. Berlin 1998. pp. 1-26

LEWIS LD, MORRIS JR ML, HAND MS 1987: Small Animal Clinical Nutrition. III. Mark Morris Ass, Topeka

MATTER HC, DANIELS TJ 2000: Dog Ecology and Population Biology. In: Dogs, zoonoses and public health. CABI Publishing, Wallingford, pp. 17-62

MIKLÓSI A, TOPAL J, CSANYI V 2004: Comparative social cognition: what can dogs teach us? Anim Behav 67: $995-1004$

OVERALL KL 1997: Clinical behavioral medicine for small animals. Mosby - Year Book Inc., St. Louis. 544 p.

PODBERSCEK AL, SERPELL JA 1997: Environmental influences on the expression of aggressive behaviour in English Cocker Spaniels. Appl Anim Behav Sci 52: 215-227 
SCOTT JP 1962: Critical periods in behavioral development. Science 138: 949-958

SCOTT JP 1992: The phenomenon of attachment in human-nonhuman relationships. In: The inevitable bond. Examining scientist-animal interactions. Cambridge University Press, Cambridge. p. 72-92

SCOTT JP, FULLER JL 1965: Genetics and the social behavior of the dog. University of Chicago Press. Chicago

SCOTT JP, FULLER JL 1974: Dog behavior. The genetic basis. University of Chicago Press. Chicago

SCOTT JP, MARSTON M-V 1950: Critical periods affecting the development of normal and maladjustive social behavior in puppies. J Genet Psychol 77: 25-60

Statistická ročenka České republiky 1998. Praha. 743 p. 